\title{
E-CRM for Cooperation Service System in Higher Education Setting
}

\author{
Sujarwanto, Khofidotur Rofiah, Sri Setyo Iriani \\ Department of Special Education \\ Universitas Negeri Surabaya \\ Surabaya, Indonesia \\ srisetyo@unesa.ac.id
}

\begin{abstract}
This study aims to improve the quality of management and cooperation services that are responsive, accountable, and transparent. Based on this background, it is very necessary to have research on improving the quality of collaboration services at Universitas Negeri Surabaya. Therefore, in this study the title "Development of E-CRM (Electronic Customer Relationship Management) University Cooperation Service System to Improve the Quality of Management and Services in the Field of Planning and Cooperation in Universitas Negeri Surabaya". The implementation of the collaboration at Universitas Negeri Surabaya covers 6 (six) stages of the implementation of the collaboration namely First, the pioneering/initiation stage of cooperation. Second, the stage of drafting/endorsement/signing. Third, the follow-up stage and implementation of the collaboration. Fourth, the stage of monitoring and evaluating cooperation. Fifth, the measurement phase of cooperation partner satisfaction (customer satisfaction). Sixth, the stage of development or termination of cooperation.
\end{abstract}

Keywords-electronic customer relationship management; planning and cooperation system; cooperation service; higher education

\section{INTRODUCTION}

At present the development of the computer world in Indonesia looks better, This can be indicated from the growth of good computer use in all fields. One of them is the use of computers in the management of education providers. The use of computers in the education sector is very helpful in processing and providing information for students and educational institutions that carry out various administrative activities [1].

Higher education in Indonesia does not only develop academic education systems. But it is also non-academic which is also the focus of university development. One of them is the field of planning and cooperation within the University, which has an important role in developing institutional collaboration with other institutions both at home and abroad [2].

The flow and process that has been determined by the institution in this case is the field cooperation system so far that still needs improvement and improvement. In accordance with the priority programs that have been set by the University's collaboration field is "Arranging and managing information services in cooperation in order to realize information transparency and fostering institutional relations with other institutions in accordance with the provisions". To achieve transparent, one-door, and responsive service principles, it is necessary to design and develop a collaborative service system based on the use of technology. In this research, an e-CRM system will be designed and implemented to support the ease and transparency in the process and procedure of University collaboration services.

CRM (customer relationship management), which is the integration of a coordinated proposal, acceptance, and cooperation service strategy that aims to increase customer satisfaction [3], [4]. In this case the intended customer is the user or cooperation partner of the University consisting of (1) Government institutions both at the central and regional levels, (2) Educational institutions or private domestic and foreign, (3) Business, industry, regional companies , national and / or international companies, (4) Donors in the field of education and / or in the fields of science, politics, technology, economics, arts and culture, (5) research institutions, (6) individuals who are committed to the advancement of education , (7) National and international non-governmental organizations, and (8) Alumni [5].

The urgency of this research is to improve the quality of management and cooperation services that are responsive, accountable, and transparent. Based on this background, it is very necessary to have research on improving the quality of collaboration services in higher education. Therefore, in this study the title "Development of E-CRM (Electronic Customer Relationship Management) University Cooperation Service System to Improve the Quality of Management and Services in the Field of Planning and Cooperation in Universitas Negeri Surabaya".

\section{METHOD}

\section{A. Subjects and Research Design}

Based on the development research paradigm that finds specific problems in a particular field, this study has a subject that is Universitas Negeri Surabaya. Each stage of development will be carried out in detail and detail. That stage includes (1) Phase I: Preliminary Study (Information Collection), (2) Stage II: Preparation of equipment / instruments and the process of validation, revision and system 
development, and (3) Stage III: Test class will develop and become a Product[6],

\section{B. Data Collection Techniques}

The development of data collection in research is essential. Collecting data in qualitative research The main instrument is the researcher himself (human instrument) to search for data by interacting symbolically with the subjects studied[7]. The relationship between researchers and research subjects only applies to collecting data through activities or data collection techniques. Data collection techniques in qualitative research itself include participant observation, interviews, observations, and in-depth documentation with research subjects, document collection by reviewing various references that are relevant to the research focus[8].

\section{Data Analysis Techniques}

Analysis of qualitative descriptive development is data that appears in the form of words and not a series of numbers[7]. The steps of data analysis are in accordance with development research, namely data collection, condensation, display, and verification or conclusion drawing. In line with the expert's presentation, the data analysis process begins by examining all available data from various sources, both data from interviews, observations that have been written in the field notes at the research location, personal documents, official documents, pictures, photographs, etc[9]. The data collected is digested, analyzed, studied, processed and processed in several ways, namely: editing, typing, citing, then arranged in a text structure and expanded.

\section{Data Validity Techniques}

The validity of the data findings is an important thing in research because it will guarantee the confidence of the data findings in solving the problem under study. To establish the validity of the data, an inspection technique based on a number of criteria is needed. In this study using four criteria, namely the degree of trust (credibility), transferability, and dependability (dependability) and confirmability[7].

1. Preliminary studies (research and information gathering): through literature review conducted by research members, focus group discussions (FGD) by inviting academics and practitioners in terms of services and procedures for collaboration and information technology, as well as observations in the field of planning and collaboration at universities other. This preliminary study was conducted to identify forms of collaboration services and procedures, as well as appropriate information technology to accommodate these services. In this step, Intitut Teknologi Sepuluh Nopember (ITS) and Universitas Brawijaya (UB) were visited and were learned.

2. Planning: defining skills or abilities, setting goals

3. Initial product development, preparing the system

4. Initial trials by experts. This trial involves experts who are related to Electronic Customer Relationship Management (E-CRM) University Cooperation System Products to Improve the Quality of Management and
Services in the Field of Planning and Cooperation in Universitas Negeri Surabaya. This is intended to determine whether the research product being developed is ready for field testing. This expert test was conducted by economists and other fields as well as Information Technology experts. Data is collected through suggestions, responses and criticisms from experts which can be used as a basis for improving the product development that is produced. The expected outcome of this expert test is the Development of E-CRM (Electronic Customer Relationship Management) University-based Collaboration Service System that is feasible to use.

5. Major product revisions, product revisions as suggested by a previously appointed expert.

6. Main or small-scale field tests on potential users, namely old partners who have collaborated with Unesa. This determination is based on the consideration that the service personnel concerned have eligibility criteria. Based on inputs, responses and suggestions, the product trial design was analyzed as a revision of the E-CRM (Electronic Customer Relationship Management) University Cooperation Service System product to Improve the Quality of Management and Services in the Planning and Cooperation Field at the Universitas Negeri Surabaya. The expected outcome of this small-scale field test is the development of a user-friendly E-CRM (Electronic Customer Relationship Management) University Cooperation System.

7. Revised main or small scale field test results

8. Real or large-scale field tests on prospective users, namely all cooperation partners in Unesa. Based on input, responses and suggestions, the product trial design was analyzed as a product revision of the E-CRM (Electronic Customer Relationship Management) University Cooperation System Development product. The expected outcome of this large-scale field test is the Development of an E-CRM (Electronic Customer Relationship Management) -based University Cooperation Service System that is effectively used.

Revision of final products of real or large-scale field test results. The steps consisting of the nine stages of the cycle mentioned above are an interconnected series. In this research phase if the product development does not meet the criteria, then the product design needs to be revised and analyzed until the product stage is ready for use. This development research resulted in the Unesa ECRM (Electronic Customer Relationship Management) University-based Cooperation System Development Product that is ready to be disseminated.

The data obtained are basically in the form of: (1) Quantitative data, this data is obtained using instruments given to each prospective user, when conducting small-scale or large-scale field trials, and (2) qualitative data, this data is obtained with interviews and discussions with experts. In addition, data can also be obtained from notes, criticisms, suggestions from experts on the content and design of E-CRM (Electronic Customer Relationship Management) University 
Cooperation Service Systems to Improve the Quality of Management and Services in the Planning and Cooperation Field at Universitas Negeri Surabaya.

All data obtained both quantitatively and qualitatively can be used as consideration for revising and perfecting the Development of E-CRM (Electronic Customer Relationship Management) University Cooperation System.

\section{RESULTS AND DISCUSSION}

\section{A. Information System}

Information systems are components that work together to collect, process, store and disseminate information to support decision making, coordination, control, problem analysis and visualization within an organization [10]. In detail that information systems are a regular combination of people, hardware, software, communication networks and resources that collect, change, and disseminate information within an organization [9].

\section{B. Customer Relationship Management (CRM)}

Customer Relationship Management is a strategy for managing organizational relationships and interactions with customers and potential customers. CRM systems help companies stay connected with customers, streamline processes, and increase profitability. CRM is defined as the integration of coordinated sales, marketing and service strategies aimed at increasing customer satisfaction [2]. CRM stores customer information and records all contacts that occur between customers and companies, and creates customer profiles for company staff who need information about these customers [11].

In CRM there are three phases, namely acquiring (getting new customers), enhancing (improving relationships with existing customers), and retaining (retaining customers). Each phase supports increased intimacy and understanding between the company and its customers [4].

\section{CRM Operations}

Operational CRM is an application that interacts directly with users (customer-facing) which integrates fronts, backs and mobile offices, including sales force automation (SFA), enterprise marketing auto-mation (EMA), and customer service and support (CSS). Operational CRM, also known as "front-office" CRM, involves areas where direct contact with customers occurs.

\section{Dimensions of Customer Relationship Marketing}

Based on the definition of relationship marketing (CRM), there are several indicators that can be considered in implementing customer relationship marketing (CRM) as a marketing strategy. These indicators will help companies to more easily identify customer relationship marketing (CRM) indicators that are considered and chosen by customers. Companies can group customer relationship marketing (CRM) indicators based on the quality of the customer-bank relationship. The expert proposed six dimensions of relationships consisting of interdependence, self concept connections, commitment, love/passion, intimacy and parner quality. These six dimensions of relationship quality reflect several indicators of CRM customer relationship marketing strategies developed by other marketing experts identifying the dimensions of relationships based on the social psychology approach [12], as presented in Table 1 .

TABLE I. RELATIONSHIP DIMENSIONS

\begin{tabular}{|c|c|}
\hline $\begin{array}{ll}\text { - } & \text { Trust, ethics } \\
\text { - } & \text { Commitment } \\
\text { - } & \text { Can be trusted } \\
\text { - } & \text { Proximity } \\
\text { - } & \text { Understanding, empathy } \\
\text { - } & \text { The same purpose } \\
\text { - } & \text { Value shared } \\
\text { - } & \text { Reciprocal relationship } \\
\text { - } & \text { Respect, sincerity } \\
\text { - } & \text { Attention, affection, love }\end{array}$ & $\begin{array}{ll}\text { - } & \text { Dependency } \\
\text { - } & \text { Awareness of the other party's } \\
\text { - } & \text { history } \\
\text { - } & \text { Warmth, intimacy } \\
\text { - } & \text { Interest in needs } \\
\text { - } & \text { Knowledge } \\
\text { - } & \text { Responsive } \\
\text { - } & \text { Keeping promises } \\
\text { - } & \text { Community social support } \\
\text { - } & \text { Competence }\end{array}$ \\
\hline
\end{tabular}

\section{3. $E-C R M$}

E-CRM or customer relationship management includes all CRM functions using a network environment such as intranet, extranet and internet. E-CRM concerns all forms of managing customer relationships utilizing information technology (IT). E-CRM is the use of IT by companies to integrate internal organizational resources and external "marketing" strategies to understand and meet the needs of their customers [11].

\section{CONCLUSION}

Higher education environment need to be accessible for every people in all kind of field, especificaly planning and cooperation services system in University. Designing and using technology is the best way to archive that goals. Universitas Negeri Surabaya by cooperation system based on E-CRM will give the transparance access for everyone who want to collabote.

\section{REFERENCES}

[1] E. M. Heen, "Teaching Unprepared Students: Strategies for Promoting Success and Retention in Higher Education-By Kathleen F. Gabriel," Teach. Theol. Relig., vol. 13, no. 1, pp. 73-75, 2010.

[2] B. A. MacNaughton and L. R. Turner, "System for intergrating an online service community with a foreign service." Google Patents, 18Aug-1998.

[3] N. C. Romano Jr and J. Fjermestad, "Electronic commerce customer relationship management: An assessment of research," Int. J. Electron. Commer., vol. 6, no. 2, pp. 61-113, 2001.

[4] S. A. Brown and P. W. Coopers, Customer relationship management: A strategic imperative in the world of e-business. John Wiley \& Sons, Inc., 1999.

[5] D. Jutla, J. Craig, and P. Bodorik, "Enabling and measuring electronic customer relationship management readiness," in Proceedings of the 34th Annual Hawaii International Conference on System Sciences, 2001, pp. 10-pp.

[6] M. D. Gall, W. R. Borg, and J. P. Gall, Educational research: An introduction. Longman Publishing, 1996.

[7] B. Lev and S. R. Thiagarajan, "Fundamental information analysis," $J$. Account. Res., vol. 31, no. 2, pp. 190-215, 1993.

[8] A. Srivastava and J. Thiagarajan, "Effectively prioritizing tests in 
development environment," in ACM SIGSOFT Software Engineering Notes, 2002, vol. 27, no. 4, pp. 97-106.

[9] W. H. Davidow, "The virtual corporation: Structuring and revitalizing the corporation for the 21 st century," 1992.

[10] B. R. Clark, Creating entrepreneurial universities: Organizational pathways of transformation. Issues in higher education. ERIC, 1998.

[11] N. C. Romano and J. Fjermestad, "Electronic commerce customer relationship management: A research agenda," Inf. Technol. Manag., vol. 4, no. 2-3, pp. 233-258, 2003.

[12] P. D. Wellner, "Multimedia service access by reading marks on an object." Google Patents, 17-Jun-1997. 